\section{O CENTENÁRIO DO CÓDIGO COMERCIAL DO BRASIL}

\section{Waldemar Ferreira}

Professor Catedrático de Direito Comercial na Faculdade de Direito de São Paulo.

I

O projeto no seu percurso legislativo

\begin{abstract}
1. - A vocação codificadora do século $X I X$. 2. - O Brasil e as Ordenaçóes de Portugal. - 3. - A independência do Brasit e a sobrevivência das leis portuguêsas. - 4 . - A Constituição de 1824 e os códigos por ela prometidos. - 5. - A comissão momea da pelo Govêrno para redigir o projeto de código comercial. - 6. - A exposição com que a, comissão apresentou o projeto ao Govêrno. - 7. - A influência de José da Silva Lisboa e o convite para participar dos tra balhos da comissão. - 8. - O parecer das comissões reunidas da Câmara dos Deputa dos sôbre o projeto. - 9. - A aceitaça â do projeto $e$ os debates que a propósito se trava ram confluindo pela constituição de comissão mista de senadores e deputados para o estudo do projeto. - 10. - A votação do projeto pela Câmara dos Deputados. - 11. - Os trâmites do projeto no Senado. - 12. - A aprovação das emendas do Senado pela Câmara dos Deputados. - 13. - A sancão promulgação. - 14. - O sentido nacional do código comercial. - 15. - $O$ código como um dos mais notáveis da sua época e sua vigência centenária.
\end{abstract}

1. Caracterizou-se o século passado pelo espírito jurídico que o animou. Afirmou êle, no judicioso reparo de GEORGES RIPERT, a soberania da lei para governar os homens; e, em todos os países, códigos promulgaram-se a fim de ministrar a todos a regra a seguir $\left.{ }^{1}\right)$. Não se enganou, por isso mesmo, o grande SAVIGNY, quando, ao opor-se ao apêlo de THIBAUT, deslumbrado pelo sucesso do código civil napoleônico, por que também na Alemanha se elaborasse obra idêntica, salientou a vocação do século para a legislação e a jurisprudência. Enérgica entremostrou-se a apóstrofe do romancista contra os códigos, que lhe pareceram falsos e arbitrários porque feitos com idéias sistemáticas e ignorância do desenvolvimento histórico do direito. Os códigos, de resto, êle o disse, impediriam que a ciência marchasse com o século, imobilizariam o espírito dos jurisconsultos, prendendo-os a suas fórmulas, e privariam o direito de aperfeiçoamento, vedando a livre interpretação de seus textos. Receou o jurista que o código civil francês, que, "a modo de gangrena", se propagava em seu país, viesse a conspirar contra a unidade germânica, a despeito de seu caráter geral de superficialidade e de incerteza $\left({ }^{2}\right)$.

Motivo foi êsse, de entre outros, por que a Alemanha se mostrou retardatária no codificar o seu direito privado, a despeito de que, antes mesmo de sua unificação política, se houvesse batalhado no sentido de codificá-lo, o que, a bem dizer, só veio a acontecer no fim do século. $\mathrm{O}$ código civil alemão de 18 de agôsto de 1896 só se tornou vigente a partir de 1 de janeiro de 1900, há pouco mais de cinqüenta anos.

É que, como prelecionou nesta Faculdade de Direito o Conselheiro RIBAS, não se compreende que o povo, que tenha leis completas, embora esparsas em grande número de atos, as refunda e codifique simplesmente "pelo amor da simetria formal".

Os códigos não são, não podem ser obras artificiais, simples lavores técnicos, que se preparem porque sejam de moda e nos países mais adiantados se encontrem. Desdenhou dêles a Inglaterra, onde em verdade inexistem, com os caracteres solenes de que se revestem, no pressuposto de sua imperecibilidade. Os códigos franceses dos primórdios do século passado serviram de paradigma para os que se viram os outros países na contingência de adotar ou elaborar, servindo-se da prata de casa. Orientaram-se todos mais ou menos pelo mesmo sistema arquitetônico; mas foram ditados pelas circunstâncias nacionais.

Nem todos os povos lograram isentar-se da fatalidade histórica que os impôs aquém e além-mar, para a mais viva eficiência das normas jurídicas. "Quando", doutrinou o exímio professor pau-

\footnotetext{
(1) GEORGES RIPERT, Le Declin du Droit, ed. Librairie Genérale de Droit et de

Jurispruare F. DE SAVIGNY, De la vocacion de nuestro siglo para legislacion y la ciencia
} 
lista já referido, "quando consta a legislação de numerosos ạtos, publicados em épocas remotas umas das outras, inspirados por espíritos diversos e redigidos com, diferentes estilos, atos que se revogam $\epsilon$ se substituem uns aos outros por trechos; quando além de ser em si mesma deficiente, acha-se em contradição com o estado moral, político e econômico da sociedade atual; quando sob o impulso da lei do progresso o povo se tem completamente transformado, torna-se indispensável que a sua legislação também se transforme paralelamente, de modo que se ponha em harmonia com o estado do país; neste caso a codificação é não só vantajosa, como até indispensável"' $\left({ }^{3}\right)$.

2 - Viveu o Brasil, desde seu descobrimento, sob a égide das velhas Ordenações de Portugal, como sua colônia e seu prolongamento territorial na América. Vigoravam em 1500 as Ordenações Afonsinas, pois que havia madrugado em Portugal a sua vocação codificadora. Constituíram elas, no seu tempo, obra monumental, autêntico código, o primeiro publicado na Europa a assinalar época importante. Disse-o CÂNDIDO MENDES DE ALMEIDA. Nesse código se disciplinaram quase tôdas as matérias da administração do Estado, ao mesmo passo que se regeram as relações de ordem privada, pondo têrmo às antiqüíssimas leis feudais e consuetudinárias. Revogando a lei chamada - da avoenga, sublimou a do Corpus Juris Civilis Romanorum, equiparada à canônica, prevalecente nas matérias em que houvesse pecado (4).

Esse nobre código, encontrado por D. MANUEL, o Venturoso, ensejou, ao grande monarca faina legislativa, que o depurou e aumentou, desejoso de ligar seu nome a novo monumento legislativo, que foram as Ordenações Manuelinas, de 1521, e em que procurou fortalecer o poder real.

Como as anteriores não foram duradouras as Ordenações $\mathrm{Ma}$ nuelinas. Extinta, em 1578, a Dinastia de Aviz, iniciou-se o reinado de D. FILIPE I, da Espanha, que se preocupou de promulgar novo código, de molde a mostrar sua amizade pelos portuguêses. Mandou elaborá-lo o alvará de 5 de junho de 1595 . O empreendimento, porém, sòmente se ultimou sob o reinado de D. FILIPE II, ao qual coube a fortuna de promulgar, em 1603, as Ordenações Filipinas, pelas quais se regeu, por mais de dois séculos, a nação portuguêsa.

Eis os três códigos pelos quais também se regeu o Brasil, desde o descobrimento até a sua independência, em 1822.

3. Erigido em nação, não podia o Brasil, de um dia para

(3) ANTONIO JOAQUIM RIBAS, Curso de Direito Civil Brasileiro, $4^{a}$ ed., Jacinto Ribeiro dos Santos (Rio de Janeiro, 1915, pág. 195).
(4) CÂNDIDO MENDES DE ALMEIDA, Código Filipino, 14. ${ }^{a}$ ed. da Tipografia do

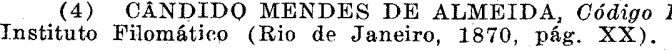

outro, mudar de leis, que se não improvisam, e que fôssem consentâneas com as cọntingências de seu novo papel histórico e político. Eis porque a lei de 20 de outubro de 1823 mandou vigorar no Império as Ordenações, Leis è Decretos, promulgados pelos Reis de Portugal e pelos quais o Brasil se governava até o dia 25 de abril de 1821, em que S. M. Fidelíssima, então Rei de Portugal e Algarves, se ausentou do país, e tôdas as que fôssem promulgadas daquela data em diante pelo Sr. D. PEDRO DE ALCÂNTARA como Regente do Brasil enquanto Reino, e como Imperador Constitucional dele, desde que se erigiu em Império, ficando em inteiro vigor na parte em que não tivessem sido revogadas, para "por elas se regularem os negócios do interior dêsté Império, enquanto se não organizar um novo Código, ou não forem especialmente alteradas".

Acenava-se, mui precisamente, para um novo código. Qual seria? Dois, a êsse tempo, faziam a glória da França: o civil, de 1803; e o comercial, de 1807.

4. Aquela lei de 20 de outubro de 1823 fôra uma das decretadas pela Assembléia Geral Constituinte e Legislativa do Império do Brasil, que se achava em funcionamento. No projeto de Constituição, que se lhe apresentou, redigido por ANTÔNIO CARLOS RIBEIRO DE ANDRADA MACHADO E SILVA, JOSÉ BONIFÁCIO DE ANDRADA E SILVA, ANTÔNIO LUÍS PEREIRA DA CUNHA, MANUEL FERREIRA DA CÂMARA DE BETENCOURT E SÁ, PEDRO DE ARAUJO LIMA, JOSÉ RICARDO DA COSTA AGUIAR DE ANDRADA e FRANCISCO MONIZ TAVARES, mais não se prescreveu, e foi no art. 199, depois de aludir ao processo civil e ao criminal, que "o código seria uniforme e o mesmo para todo o Império".

Dissolvida a Assembléia Constituinte e ditada, aos 25 de março de 1824, a Constituição elaborada por JOÃO SEVERIANO MACIEL DA COSTA, LUÍS JOSÉ DE CARVALHO E MELO, CLEMENTE FERREIRA FRANÇA, MARIANO JOSÉ PEREIRA DA FONSECA, JOÃO GOMES DA SILVEIRA MENDONCA, FRANCISCO VILELA BARBOSA, BARÃO DE SANTO AMARO, ANTONNIO LUIZ PEREIRA DA CUNHA, MANUEL JACINTO NOGUEIRA DA GAMA E JOSE' JOAOUIM CARNEIRO DE CAMPOS, focalizou o assunto. Dispôs ela, no art. 179, n. ${ }^{\circ}$ XVIII, que se organizaria "quanto antes um código civil e criminal, fundado nas sólidas bases da justiça e eqüidade”.

A menos que o texto constitucional antevisse código civil unificado, compreendendo ao mesmo contexto a matéria civil e a matéria comercial, hipótese que, ao tempo, sôbre prematura, seria inadmissível, o preceito constitucional omitiu referência ào código do comércio. 
Predominava o pensamento de JOSÉ DA SILVA LISBOA de que havia "grande e óbvio inconveniente de se englobar a legislação comercial no código civil". Escudado nas reflexões do que considerava o "maior mestre da ciência do comércio", PARDESSUS, expressas no seu Cours de Droit Commercial: "As leis civis", doutrinava o grande comercialista francês, "as leis civis não operam senão sôbre o povo a quem são dadas: elas se ressentem necessàriamente $\mathrm{da}$ influência de seus costumes, de sua organização política e de seu clima; mas as leis do comércio interessam o universo inteiro, no qual os comerciantes formam, por assim dizer, a mesma família. $O$ espírito destas leis não se pode mudar com as demarcacõos territorias; na sua providência hospitaleira, elas não devem oferecer maior garantia aos estrangeiros do que aos nacionais; e a experiência nos tem, mais de uma vez, ensinado que a sua injustiça, sendo punida nas mais horrorosas reaçôes, excita o fogo da guerra de uma a outra extremidade da terra. A estabilidade das leis é o maior benefício que um soberano possa conceder a seus povos; o comércio sobretudo não pode prosperar no meio das oscilações perpétuas da legislação" $\left(^{5}\right)$.

Tinha o primeiro e o maior dos comercialistas do tempo, ainda não ultrapassado, o preconceito do sentido universal ou cósmico do direito mercantil, que se não poderia conter na rígida armadura de outro código que não fosse o do comércio.

No cumprimento do dispositivo constitucional, quando tais palavras se escreviam no discurso preliminar das - Regras da Praça, já se haviam ultimado os trabalhos do código criminal, promulgado aos 16 de dezembro de 1830 .

5. A abertura dos portos do Brasil ao comércio direto estrangeiro, pela carta régia de 28 de janeiro de 1808 , teve a virtude de desenvolvê-lo, de molde a criar necessidades que se não poderiam atender senão por via de dispositivos legais adequados. Instituída e instalada no Rio de Janeiro, pelo alvará de 23 de agôsto de 1808 , a Real Junta de Comércio, Agricultura, Fábricas e Navegação, a praça do comércio agitou-se no sentido de preparar regulamentos. a que todos se subordinassem, para o bem-estar geral. Houve aquêle tribunal por acertado cometer ao mais autorizado de seus membros, JOSÉ DA SILVA LISBOA, a incumbência de organizar projeto de código do comércio. Essa obra, dizia êle, "essa obra hercúlea muito excedia às minhas fôrças; além de requerer superior capacidade, exigia tempo, descanso, auxílio, prática de negócios, e vigor de idade"; e tudo isso, acrescentou, veiu a faltar-lhe. (5) JOSÉ DA SILVA LISBOA, Princípios de Direito Mercantil e Leis de Marinha,
6.a ed., por Cândido Mendes de Almeida, da Tipográfia Acadêmica (Rio de Janeiro, 1874,
vol, II. pág. 931).
Amorteceu-se o empreendimento; mas não se esmoreceu a campanha com o mesmo objetivo, no decorrer dos sucessos políticos que se desenrolaram.

Referem os anais parlamentares que, em sessão de 3 de setembro de 1831, teve leitura mensagem do comércio do Rio de Janeiro, representando ao Senado sôbre a conveniência de criar-se tribunal especial para as causas mercantis. Enviada à Comissão de Constituição e Diplomacia, nela se emitiu parecer em 19 de maio de 1832 , opinando por sua conveniência e constitucionalidade, à vista do disposto no art. 179, n. $^{\circ}$ XVII, da Constituição; mas sugerindo que, tendo sido nomeada comissão para aquêle fim, se aguardasse o resultado de seu trabalho.

Já havia, realmente, a Regência, em nome do Imperador, em março daquele mesmo ano de 1832 , comissionado $\left({ }^{6}\right)$ um magistrado, ANTÔNIO PAULINO LIMPO DE ABREU, e quatro comerciantes, JOSÉ ANTÔNIO LISBOA, INÁCIO RATON, GUILHERME MIDOSI e HONÓRIO JOSÉ TEIXEIRA, a fim de elaborar o projeto do código comercial.

Veiu a comissão, assim constituída, a alterar-se. A recusa de HONÓRIO JOSÉ TEIXEIRA levou para ela LOURENÇO WES TIN, cônsul de Suécia, que a impregnou de dinamismo e eficiência. A investidura de ANTÔNIO PAULINO LIMPO DE ABREU, que viria a ser o Visconde de Abaeté, aos 3 de maio de 1832, na presidência da Câmara dos Deputados, ensejou a nomeação de JOSÉ CLEMENTE PEREIRA para presidíla e redigir o vencido. A alta competência dêste cidadão eminentíssimo, nascido em Portugal, bacharel formado em cânones e em leis pela Universidade de Coimbra nos últimos dias de 1809, dispensado dos atos pela ordem régia de 11 de outubro daquele ano, que assim beneficiou e laureou os estudantes que formaram o corpo militar acadêmico que se formou sob o comando de general $\mathrm{N}$. Trant para combater a segunda invasão francêsa, e que levou à frente três professôres universitários, um dos quais foi JOSÉ BONIFÁCIO DE ANDRADA E SIL-

(6) A cada qual dos comissionados dirigiu o Ministro da Justica a seguinte carta: "Sendo desgraçadamente a todos notória a decadência e míngua em que se acha de
presente o comercio brasileiro, e a que além de outras causas, tem muito principalmente dado origem a falta de um código próprio, que regulando as transacôes comerciais, assegure má fé, e contra muitos dolos e crimes, que no comércio podem cometer-se; a Regência: Querendo vivificar êste tão importante ramo da riqueza do Brasil, e promover por meio Há por bem. em nome do Imperador, que uma co

em tal matéria, à vista do que se acha dispostos nos códigos, leis e decretos especiais da

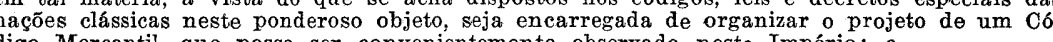
Dignando-se a mesma Regência nomear a Vm. para fazer parte da dita comissão, es-
pera do seu patriotismo e honra que se năo escuse de contribuir com o contingente do suas luzes para um trabalho de tão reconhecida vantagem e utilidade. 
VA, de filosofia; a vivacíssima inteligência de JOSÉ CLEMENTE PEREIRA asseguraria o sucesso do empreendimento.

Trabalhou com afinco a comissão. Ultimou ela o seu trabalho aos 9 de agosto de 1834, data em que apresentou ao govêrno o projeto, que havia elaborado, contendo 1.299 artigos, compreendidos em três partes, atinentes a primeira às pessoas do comércio, aos contratos e às obrigações; a segunda ao comércio marítimo e a terceira às quebras. Acresceu-se-lhe título complementar, desdobrado em 91 artigos sôbre a administração da justiça nas causas comerciais.

6. $\mathrm{Na}$ exposição, com que apresentou a comissão o projeto ao govêrno, ela salientou as diretrizes por que se orientou:

"Duas-idéias capitais ocorreram à comissão ao encetar os seus trabalhos:

" $10^{\circ}$, que um código de comércio deve ser redigido sôbre os princípios adotados por tôdas as nações comerciantes, em harmonia com os usos ou estilos mercantis, que reúnem debaixo de uma só bandeira os povos do novo e do velho mundo;

" $2 .^{\circ}$, que um código de comércio deve ser ao mesmo tempo acomodado às circunstâncias especiais do povo para quem é feito.

"Fácil foi à comissão desempenhar a primeira parte dos seus deveres: para isso consultou os códigos mais conhecidos, especialmente o da França, o da Espanha e o de Portugal, assim como os escritores de direito comercial mais notáveis; aproveitou de todos. o que julgou mais conveniente, e está inteiramente convencida de que não se desviou do que tem sido geralmente admitido pelos melhores códigos de comércio. Mas, ao entrar no desempenho da segunda parte, desanimou; e houvera dado de-mão à emprêsa se a necessidade de obedecer não lhe vedara.

"Com generosa, liberal e benfazeja mão abriu o govêrno as portas do comércio do Brasil, que uma política mesquinha conservava fechadas; mas não era bastante impelir a nação ao grande movimento que devia marcar a época do seu engrandecimento futuro: era ao mesmo tempo necessário pôr ao alcance de todos os comerciantes os princípios fundamentais da profissão que se queria fazer florescer e portanto estabelecer leis protetoras da boa fé e. coercitivas da fraude e da imoralidade.

"Semelhante falta produziu os funestos resultados de que infelizmente temos sido testemunhas.

"Estas considerações fizeram crer à comissão que, atenta a posição excepcional do país e a falta de conhecimentos teóricos e práticos da ciência comercial, convinha introduzir no código disposiçôes preventivas, que guiassem o comerciante em todos os atos de sua vida comercial.

"Na coordenação das matérias seguiu a comissão, no essencial, a todos. os códigos que teve presentes.
"Dividiu o código em três partes: cantis;

"1. ${ }^{\circ}$, das pessoas do comércio; dos contratos e obrigações mer-

" $2 .^{\circ}$, do comércio marítimo;

" $3 . \circ$, das quebras.

"Na falta de código do processo comercial, que por escassez de tempo não lhe foi possível organizar, oferece a comissão uma Disposição provisória, sôbre a administracão da justiça comercial para servir de base ao regulamento do poder executivo, que tornará exeqüível a lei comercial, enquanto não fôr adotado o código do processo.

"Na redação da primeira parte, aos artigos que se encontram em quase todos os códigos, não pôde dispensar-se a comissão de acrescentar alguns que aumentam a severidade das exigências relativas à exação da escrituração mercantil. Não era possível ser indulgente nesta parte, sendo certo que da falta de escrituração têm vindo ao comércio, em tôda a parte, e entre nós principalmente, os maiores danos.

"A falta de exação no cumprimento de obrigações verbáis tem-se tornado notòriamente prejudicial ao comércio, que não pode ser pontual nos pagamentos quando se lhe dificultam os meios de receber. Este mal foi providenciado com remédios preventivos que cortam os abusos pela raiz.

"A falta de publicidade dos contratos e outros atos mercantis tem sido a fonte de inumeráveis fraudes, que têm ocasionado a ruína dos credores de boa fé: para evitar isso fica criado o registro público do comércio.

"O comércio não pode independer de corretores: nunca os houve no Brasil, porque alguns homens que se têm alcunhado dêsse nome jamais tiveram fé pública, nem responsabilidade, requisitos sem os quais não pode haver corretores. Êstes agentes auxiliares dó comércio receberam uma regulamentação, na qual, a par da designação de seus deveres, se estabelecem as penas de suas omissões e prevaricações, acompanhadas da garantia de uma fiança.

"Nenhuma legislação existia que regulasse com segurança e certeza os direitos e obrigações dos prepostos, guarda-livros, caixeiros, condutores de gêneros, tropeiros e de administradores de trapiches e armazéns de depósito: esta lacuna foi providenciada com disposicões adequadas às circunstâncias especiais do país.

"Na redação dos contratos mercantis observou a comissão que os melhores códigos se limitavam a estabelecer as exceçôes relativas ao comércio, remetendo-se no mais às disposições gerais dos códigos civis. Nesta parte, firme a comissão no princípio de que convém dar aos nossos comerciantes normas diretoras de todos os atos mercantis; e atendendo a que as leis civis do Império são escassas. 
em matéria de contratos, ordenou títulos completos das diversas naturezas dos contratos admissíveis em comércio, nos quais pensa ter substanciado as regras que podem ter aplicação nas transações mercantis.

"A matéria de sociedade for extensamente tratada, de acôrdo com a ciência moderna e com o desenvolvimento do comércio.

"Sobretudo a matéria das letras, êsse meio circulante poderoso, que transporta os fundos comerciais a tôdas as partes do mundo, geralmente mal entendida, mereceu, e nem podia deixar de merecer particular atenção da comissão, a qual, coligindo em sistema tudo quanto achou escrito, aditado do que julgou conveniente, espera que questões desta ordem, quando se apresentarem, serão decididas com a precisão e justiça que o direito cambial prescreve e a boa fé mercantil exige.

“Um título sôbre prescrições, por sua natureza mais curtas em comércio, fecha o trabalho da primeira parte do projeto do código.

" $\mathrm{Na}$ segunda parte do projeto achou-se a comissão ligada a deveres mais restritos. As bases do direito marítimo acham-se originàriamente na legislação dos primeiros povos navegadores.

"Depois que LUÍS XIV a reduziu a sistema, a famosa Ordenança de 1681 tornou-se o código universal de todos os comerciantes. Nenhum redator dos códigos comerciais, depois dela publicados, ousou até hoje alterá-la: fôra, pois, um crime da comissão se ousasse tomar a iniciativa de fazer inovação em princípios que têm em si a essência da imutabilidade; copiou fielmente artigos que todos os códigos têm copiado daquela fonte tão rara: era êste o seu dever, e ela o cumpriu.

"A matéria de seguros marítimos e avarias fêz recuar mais de uma vez a comissão, que quanto mais aprofundava a discussão, mais desconfiava da sua obra. Aumentava os embaraços da comissão o doloroso exemplo das companhias de seguro desta Côrte, desgraçadamente sacrificadas pela inexperiência dos seguradores e pela fraude manifesta dos segurados, e até algumas vêzes por decisões arbitrais ou dos tribunais pouco conformes aos verdadeiros princípios da natureza do contrato. Felizmente achou a comissão no fôro inglês, nas compilações de MARSHALL e ALLAN PARK, a prática dos princípios exatos que procurava; e sôbre esta ilustração levantou os títulos de seguros e avarias, e confia que, se a obra não é perfeita, pelo menos contém regras precisas e claras que, se forem bem entendidas na execução, tornarão certa e incontroversa esta parte, a mais importante do direito marítimo, até hoje confusa e vacilante no Império.

"A parte terceira do projeto, dedicada às quebras, foi redigida segundo os princípios e disposições dos códigos mais acreditados, com as modificações e alterações que a comissão entendeu exigidas pelas circunstâncias do país.

"O código comercial é inexeqüivel sem o código do processo: a cada passo se refere a êste, e está concebido de forma que exige o juízo por jurados em muitos casos importantes. A comissão tinha já concebido o seu plano, mas por escassez de tempo não pôde ultimar êsse trabalho com a brevidade que dela se exige.

"Para suprir essa falta redigiu as bases sôbre que pretendia organizar o projeto do código do processo; e entende que, sendo estas desenvolvidas em regulamento do poder executivo, poderá o código do comércio ser exeqüível sem inconveniente, enquanto aquêle não fôr publicado.

"Tais são os princípios gerais sôbre que está baseado o projeto do código comercial.

"Se êle puder merecer a adoção da Assembléia Geral Legislativa, a comissão se dará por bem paga do árduo trabalho e longas vigílias que empregou na redação e organização da obra”.

7. Ressumbra das palavras justificativas do projeto a modéstia de seus autores. Não se ufanaram de inovadores. Esmeraram-se, por isso mesmo, em proclamar, com desusada lealdade, a ausência de originalidade de seu trabalho. Se, por um lado, tiveram diante dos olhos os três códigos comerciais até então promulgados - o da França, o da Espanha e o de Portugal,. muito havia que recolher e dar forma tanto na doutrina, imperante no Brasil, quanto na prática do comércio brasileiro.

$\mathrm{Na}$ doutrina, duas edições já haviam saído do prelo dos Princípios de Direito Mercantil e Leis de Marinha, de JOSÉ DA SILVA LISBOA, que seria logo depois o Visconde de Cairú. Aquêle grande tratado, que foi o primeiro escrito em língua portuguêsa e um dos mais notáveis até então aparecidos no mundo pelo seu conjunto sistemático e, sobretudo, pelo vigor dos ensinamentos, constituía o breviário de quantos se propusessem estudar ou resolver qualquer dificuldade teórica ou prática da ciência e da arte do comércio. Não tomou parte o comercialista inigualável e inigualado na comissão elaboradora do projeto do código comercial, pelas contingências da vida política nacional.

"Depois", êle o disse com indisfarçável amargura no discurso preliminar das REGRAS DA PRAÇA, "depois da declaração da Independência do Império, fui encarregado por ordem superior de escrever a HISTÓRIA DO BRASIL. Havendo apresentado a parte primeira, pedi permissão de pausa, para continuar no trabalho do Código, apresentando um plano à Secretária de Estado dos Negócios do Império; e pôsto fôsse deferida favoràvelmente a minha súplica, recomendou-se-me contudo que não me esquecesse da ordenada principal crônica dos sucessos dignos de memória, ocorridos 
de 26 de fevereiro de 1821 em diante, ao que satisfiz quanto pude, relatando o período decorrido desde aquela época até o dia 12 de outubro, da Aclamáção do então Princípe Regente do Brašil. Seja-me agora permitido dizer com o parlamentário de Inglaterra, GRANVILLE, no seu moderno opúsculo sôbre - O Fundo de Amortização, em que se retratou a sua opinião, que quarenta anos antes havia sustentado com PITT: "Envelheci sempre muitas coisas aprendendo". Tendo por fim lido o novo código de 'comércio da Espanha e outras obras estrangeiras sôbre as relações comerciais, resolvi-me a concluir, tal qual pude fazer, um esbôço provisório de regimento do "comércio, em desempenho da obrigação oficial".

E, como que fazendo o seu testamento científico aberto, desenvolveu, ho opúsculo, que então se editou, as suas opiniões, que objetivavam, ineqüivocamente, os que estavam incumbidos de redigir o projeto do código comercial. O opúsculo foi o - das Regras da Praça ou Bases de regulamentação comercial conformé aos novos códigos de comércio da França e Espanha e a legislação pátria com oportunas modificações de estatutos e usos das nações civilizadas.

Afastado, por injunções políticas $\left({ }^{7}\right)$ da incumbência, que seria a de seu maior agrado e de sua predileção, não quis, entretanto, silenciar; e eis porque tornou públicas as suas sugestões para o aprimoraménto do projeto que se preparava.

Não se cuidou de legislar ao Deus dará, tanto mais que o comércio, embora contido, até 1808 , nas malhas asfixiantes do sistema colonial, sobremodo se desenvolvera, adquirindo novos usos e costumes, adotando novas fórmulas contratuais; e tudo isso reclamava providências legislativas salutares. Os preceitos da velha legislação reinícola, que Portugal já havia proscrito com o advento do seu código de comércio de 1833 , não mais se compadeciam com as necessidades brasileiras.

Teria o projeto satisfeito aos anseios dos comerciantes?

(7). Diante dos reparos, que explodiram na imprensa, provocados pelo fato de não
ter sido o Visconde de Cairú inclú́do na comissão do rojeto do código do comércio, recebeu ter sido o Viscond
êle êste , oficio:

"Ilmo. Sr.
"Há por bem significar a V. Excia. que, tendo sido criada uma comissão de homens probos e inteligentes para organizar um projeto de um Código Mercantil, de que tanto devida à sua grande reputacáo literária; principalmente em semelhantes matérias, como o mundo sabe; mas, porque oprimido de suas habituais enfermidades, receasse a mesma
Rexência incomodar ainda V. Excia, com o acréscimo de novos trabalhos, além dos de sua Rexência incomodar
ordinária obrigação.

"Hoje, porém, certa de que V. Excia., gozando de melhor saúde, e tendo mésmo preparado já alguns trabalhos sôbre semelhante código, se não esquivará de concorrer com suas luzes para obra de tao geral utilidade, e ara qual muito dependera a prosperidade do

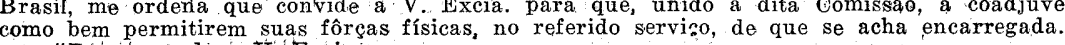
"Deis" guarde a V:." Excia..

"Paço, 11 de abril de 1832 . (a) JOSE LINO COUTINHO" de Cainu o convite, que
Fiel aos seus compromissos políticos não aceitou o Visconde de Fiel aos seus compromissos políticos, não aceitou o visconde de Cairú o convite, que
em tais têrmos lhe foi enderecado, deixando de coparticipar dos trabalhos do projeto do
código comercial.
8. Encaminhado à Câmara dos Deputados, ali recebeu parecer, em 9 de setembro de 1834, das Comissões reunidas de Comércio Agricultura, Indústria e Artes, e de Justiça Criminal, Redigiu-o o Deputado FRANCISCO DE SOUSA MARTINS, do Piauí.

"Conquanto", disseram elas, "conquanto não seja possível às Comissões pronunciar o seu juízo sôbre o merecimento individual de cada um dos diferentes artigos do projeto, pois para isso forra mister o trabalho de muitos meses, precedido do estudo de tôdas as matérias comerciais, que, são muitas, variadas e importantes; todavia acham-se habilitadas em conseqüência do exame a que procederam, para poder informar a esta Augusta Câmara o seguinte:

"1. Q Que o projeto do código comercial faz-se recomendável pela clareza, método e pureza de sua redação; qualidade esta essencial que se requer a tôda a legislação, e sem a qual ela se tornaria confusa, obscura e ininteligível;

"2. o Acha-se o mesmo projeto enriquecido de importante matéria, não se tendo omitido nêle tudo quanto se encontra de maior utilidade nos códigos da França, Espanha e Portugal, e nos escritores inglêses, na parte do direito marítimo; tendo se odicionado muitos artigos, e mesmo alguns títulos, que suposto fôssem dispensáveis e ociosos no código de outras nações adiantadas nos conhecimentos teóricos e práticos das operações comerciais, serão sem dúvida de muito proveito entre nós, já por conterem normas diretas de conduta que devem seguir os nossos comerciantes, a maior parte dos quais se acha muito atrasada naqueles conhecimentos, já por falta de legislação civil clara e apropriada, em muitos casos nos mesmos títulos prevenidos.

"3. " Devendo os códigos comerciais de tôdas as nações serem uniformes nas suas disposições legislativas, o mais que fôr possível, pois que sendo o povo comercial um só em todo o mundo civilizado, não viverá em harmonia se não fôr governado pelos mesmos usos e costumes comerciais, as Comissões confrontando diversas partes do projeto com os lugares paralelos de outros códigos comerciais, verificaram que esta qualidade indispensável se acha exatamente desempenhada. E se algumas alterações oferece o projeto, elas assentam sôbre o conhecimento prático das circunstâncias especiais do país; e nisto não faz o projeto mais que imitar os outros códigos comerciais, nos quais se encontram diversas modificações acomodadas às circunstâncias das nações respectivas, ou introduzidas por usos inveterados, que convém conservar sempre que tem por si o voto da nação que os adotou e conserva sem inconveniente.

" 4 . $^{\circ}$ Cumprindo que o código comercial de qualquer nação esteja em perfeita harmonia com a sua legislação civil e criminal, observaram as Comissões que o projeto guardou escrupulosamente esta harmonia, fazendo aplicação do código criminal sempre que 
fôr preciso fazer imposição de penas, e corformando-se com a legislação civil em tudo quanto ela era admissível. E estão as Comissõsconvencidas de que apesar dêste projeto aparo estâo as Comissões código civil que o devera preceder, por ser êste a lei geral, e aquêle uma lei de exceção, está trabalhado por tal forma que o código civil poderá vir a concordar com o comércio em regular código civil até não duvidam avançar as Comissões que aquêle poderá vir aproveitar dêste muitos títulos, com bem pequenas alterações e aditamentos; e tais são por exemplo os títulos sôbre contratos, prescrições, e preferências, e registros de hipotecas; sendo um dever das Comissões confessar que nesses títulos o projeto substanciou tudo quanto há de mais importante na matéria com exatidão e boa ordem, fazendo-se sobretudo notáveis os títulos sôbre prescrição e preferência, matérias até hoje mal providenciadas na legislação exis-

"5. O Padecia atualmente o comércio e o fôro grande necessidade de legislação previdente relativamente às sociedades e às transações cambiais. $\mathrm{O}$ projeto mostra ter conhecido esta necessidade pela amplitude com que tratou estas duas importantes matérias; e entendem as Comissões que esta lacuna tão prejudicial ao comércio, que a legislação oferecia, ficará perfeitamente suprida.

" $6 .^{\circ}$ Conferiram as Comissões a parte do direito marítimo do projeto com outros códigos marítimos e ficaram satisfeitas de ver que o projeto não só respeitou artigos, que todos os códigos têm copiado uns dos outros com religioso escrúpulo, mas até empregou um cuidado especial em que a redação e o método tornasse mais inteligíveis matérias, que em todos os temposento tornasse mais curas e dificultosas ainda mesmo aos homens de direito mais apli-
cados.

"Na parte que trata das quebras, acharam as Comissões: um trabalho, na sua opinião, completo, não só pela adocão das regras estabelecidas, assaz previdentes e exatas, mas até pela simplicidade e propriedade do processo ou fórmulas; e ousam as Comissões esperar que se a lei fôr nesta parte religiosamente executada teremos de ver desaparecer com brevidade o escândalo iritatada teremo comerciantes fraudulentos diàriamente se apresentavante collidue sempre impunemente, sem que todavi sof gua em seu rata sem que todavia sofressem quebra nem míngua em seu tratamento pessoal, desfrutando em serena paz o dinheiro alheio, como prêmio de suas criminosas prevaricações.

"Fôra na verdade para desejar que um projeto de código do processo comercial, trabalhado com igual desvêlo e sucesso, tivesse acompanhado o projeto do código comercial; a obra, então, fôra completa. Na falta dêle, e como muito convenha que o código do comércio tenha quanto antes execução, as Comissões entendem que será conveniente adotar as bases propostas pela Comissão externa, no título único da disposição provisória da administração da justiça comercial; porque nessas bases se contém regras suficientes para sôbre elas poder o govêrno organizar um bom regulamento, e com êste será o mesmo código exeqüível.

"É verdade que as referidas bases oferecem alterações notáveis nas fórmulas do processo atualmente em prática, propondo u'a marcha em tudo sumária, e o julgamento por jurados em muitos casos; mas tais alterações são há muito tempo reclamadas por todos aquêles que conhecem a gravidade dos males que resultam às partes de fórmulas que tornam as demandas eternas, e pelas que anelam ver um ensaio da instituição do júri nas causas comerciais. As causas comerciais são inquestionàvelmente as mais próprias por sua natureza para o ensaio de uma reforma no processo civil, tanto em relação à simplificação dos têrmos e das fórmulas, como ao juízo para os jurados; e debaixo desta consideração até será conveniente a adoção da forma do processo comercial, que a Comissão externa propõe, porque se êle provar bem na prática, fácil será fazer-se dêle uma aplicação a tôdas as causas cíveis no todo ou em parte. Nem será grande perigo que resulte do ensaio, visto que o govêrno pode ocorrer imediatamente a qualquer embaraço, emendando o seu regulamento, segundo forem exigindo as ocorrências.

E já temos um exemplo na reforma que a disposição transitória fêz na administração da justiça civil, a qual estabelecendo um sêco esqueleto bem poucas bases, foi exequíivel por meio do regulamento do govêrno, e muitos melhoramentos têm daí recebido a administração da justiça.

"Uma lacuna importante encontraram as Comissões nas bases propostas para o processo; e vem a ser, que não sendo praticável a instituicão de tribunais do comércio senão nas capitais das Províncias, e em algumas até talvez nem mesmo nas suas capitais, o código comercial será inexeqüível naqueles lugares do Império que se acharem distantes do assento dos tribunais, na parte em que a sua execução é privativa dêstes. Mas esta falta pode bem ser suprida no regulamento do poder executivo, enquanto a Assembléia Geral não providenciar pela forma que fôr mais conveniente.

"À vista do exposto, sendo reconhecida a urgente necessidade que o comércio padece de um código comercial, entendem as Comissões que a Assembléia Geral prestará uma considerável proteção ao mesmo comércio, se se dignar adotar quanto antes o projeto de que se trata.

"E reconhecendo por uma parte que o mesmo projeto não apresenta inconvenientes, que possam fazer recear que a sua adoção, tal qual se acha, será inexeqǘvel ou prejudicial na execução, sendo pelo contrário necessário confessar que êle é uma obra se não perfeita, pelo menos de muito merecimento; e sendo de tôda a evi- 
dência por outra parte, que uma discussão sôbre cada um dos seus artigos é impraticável, não só porque levaria muitos anos, mas também porque daria ocasião talvez a emendas, que poderiam muito bem destruir a unidade de um sistema regular e pensado, o que o mesmo projeto oferece, entendem as Comissões que a discussão é inadmissível.

"Sôbre as considerações expedidas, as Comissões são de parecer que se adote sem discussão o projeto do código comercial, e o título único - da administração de justiça nas causas de comércio, que acompanha o mesmo projeto".

9. Detiveram-se as comissões reunidas da Câmara dos Deputados diante da magnitude do problema legislativo que se lhes deparou. Havia, de um lado, a atender aos reclamos do comércio pela urgência do código, que aspirava; de outro, a superioridade do projeto preparado por comissão de comerciantes astutos e conhecedores de suas necessidades mais prementes, sob as vistas e a direção de juristas e homem de Estado de grande renome, como JOSÉ CLEMENTE PEREIRA, que não tardaria a emprestar a sua sabedoria e o seu senso prático na tarefa, que logo depois the caberia, de redigir o regulamento que viria a ser aprovado pelo decreto n. $^{\circ} 738$, de 25 de novembro de 1850 , e de que já dera testemunho na feitura do código criminal de 1830. Pareceu, nesse transe, às comissões reunidas que o mais acertado seria adotar logo o projeto $\left({ }^{8}\right)$. Não valeria a pena retardar a sanção imperial para que entrasse a executar-se. Devia aprovar-se o projeto sem que fôsse discutido, sobretudo porque, examinado artigo por artigo, isso "levaria muitos anos" e "daria ocasião talvez a emendas, que poderiam muito bem destruir a unidade de um sistema regular e pensado".

Argumento dêste naipe surge sempre que às câmaras legislativas se apresentam grandes projetos de leis e de códigos. Há sempre o receio de que o debate e, especialmente, a interferência de muitos ainda não bem afeitos ao problema examinado, lhe quebrem

(8) parecér concluiu propondo a seguinte resolução:
"A Assembléia Geral Legislativa resolve:

"A Assembléia Geral Legislativa resolve: administração de Justifa nas causas do comércio, que acompanha o mesmo projeto. Da "Art. $22^{\circ}$ - O Govêrno fica autorizado para organizar um regulamento adequado a boa e pronta execuẹá do mencionado Código Comercial, e a fazer as despesas que forem
necessárias a tim de que o mesmo Código possa ter quanto antes a execucão, dando de necessárias a fim de que o mesmo Códizo
tudo parte à Assembléia Geral Legislativa.

"Art. 3.o. O O expediente de todo quanto fôr relativo à execugáo do mesmo Código,
e ao expediente dos Tribunais do Comércio, pertence à Secretaria de Estado dos Negócios da Justica.

"Art. 4.0 - Fica extinto o Tribunal da Junta do Comércio, conservando-se aos Deputados e empregados que no mesmo atualmente servem os seus. respectivos ordenados,

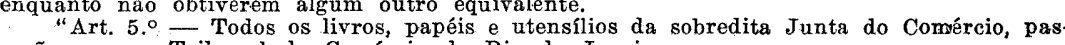
sarão para o Tribunal do Comércio do Rio de Janeiro.
"Pą̧o da Câmara dos Deputados, 9 de setembro de 1834", a unidade, afeiando-lhe o estilo e, de certo modo, enfraquecendo o sistema por que se estruturou. Acontece tal algumas vêzes. $\mathrm{Na}$ generalidade dos casos, todavia, a colaboração é sempre bem vinda, pois que supre deficiências, decepa excessos e, não raro, aprimora o fraseado.

Indo ao plenário da Câmara dos Deputados em junho de 1835, provocou o parecer a reação natural de quantos se haviam já preparado em projeto de tamanha relevância. Combaparado para colaros deputados, entre os quais, BERNARDO JOSÉ teram-no inúmeros deputados, entre os quais, BERNARDO GO Gisconde de Goiana, do Pará, e HONORIO HERMETO CARNEIRO LEÃO, de Minas Gerais, e que viria a ser o Marquês do Paraná. Tomaram êstes a dianteira nos debates. Qual estava concebido e redigido, afirmavam, o projeto não podia passar; antes, requeria emendas. Mais, ainda, reclamava melhor mais atento exame no seu conjunto e nas suas particularidades. Devia discutir-se, como qualquer lei ordinária, em globo, senão mesmo artigo por artigo. O código deveria ser condigno da cultura jurídica do país. $O$ parecer das comissões reunidas não podia vingar. Ao cabo de debates que se prolongaram por alguns dias, tornou-se vitoriosa proposta mercê da qual a Câmara dos Deputados designaria três de seus membros e convidaria o Senado a eleger outros três a fim de que, em comissão mista, de novo se examinasse o projeto, tomando em consideração as emendas, que se apresentassem, introduzindo-lhe ademais as convinháveis para que de tudo afinal conhecesse a Câmara dos Deputados, deliberando pelo melhor.

Cumprindo a proposta do Deputado FRANCISCO DE PAULA ARAUJO E ALMFIDA, da Bahia, a Câmara elegeu o VISCONDE DE GOIANA, do Pará; JOÃO JOSÉ MOURA MAGALHÃES, da Bahia; e o Padre MANUEL JOAQUIM DO AMARAL GURGEL, lente catedrático do Curso Jurídico de São Paulo.

Tão grande era o prestígio que haviam granjeado os membros da comissão elaboradora do projeto do código comercial, que, em sessão de 23 de junho de 1935 , a Câmara aprovou proposta do Deputado Padre ANTÔNIO JOÃO DE LESSA, da Província do Rio de Janeiro, redigida em têrmos incisivos:

"Que os nomes dos redatores do projeto do código do comércio sejam levados à ata em testemunho de gratidão".

Aos três Deputados juntaram-se os eleitos pelo Senado; MARIANO JOSÉ PEREIRA DA FONSECA, Marquês de Maricá, Senador pela Província do Rio de Janeiro; JOÃO ANTÔNIO RODRIGUES DE CARVALHO, pela do Ceará; e FRANCISCO DE PAULA SOUSA E MELO, pela de São Paulo.

Foi rápido o trabalho conjunto, qual se infere do sucinto parecer ministrado em 11 de outubro de 1835.

$10-$ R. D. $1 .^{\circ}$ Vol. 
"As comissões", e melhor é reproduzi-lo, "as comissões especiais nomeadas pelo. Senado e pela Câmara dos Deputados para examinarem reunidas o código do comércio, julgam de seu dever dar conta dos seus trabalhos antes de encerrar-se a presente sessão legislativa. As comissões, reconhecendo a importância da tarefa que lhes foi confiada, e ambicionando acompanhar o conceito que nêles depositaram suas respectivas câmatas, não se poupara em empregar quanto estêve de sua parte para apresentarem quanto antes êste código, que as necessidades do comércio altamente reclamam. As comissões mistas de justiça civil, justiça criminal, de comércio, indústria e artes, encarregadas o ano passado pela Câmara dos Deputados de reverem o mencionado código, já haviam dito em seu parecer de 9 de setembro de 1834, que pensavam que, o código devia ser adotado por o acharem conforme com as doutrinas dos melhores códigos da Europa; as comissões especiais repetem o mesmo parecer, acrescentando que o código do comércio do Brasil nada tem a invejar à legislação da França, Inglaterra, de Portugal e da Espanha: êle apresenta em um todo sistemático o que há de melhor nesses códigos, segundo as opiniões dos escritores mais entendidos nestas matérias, e adatadas às circunstâncias do Brasil.

"Emitindo êste seu juízo, não pretendem as comissões especiais inculcar que o código do comércio é uma obra perfeita. Muitas faltas, muitas imperfeições sem dúvida deviam escapar, que vistas mais perspicazes, e mais conhecedoras da matéria, seguramente teriam evitado: às comissões, porém, fica a satisfação de terem-se esmerado em cumprir seu dever, cooperando quanto estava em suas fôrças para oferecer-se ao Brasil um código do comércio, que firmando os direitos e obrigações dos comerciantes, lançando peias à fraude e ao dolo, desenvolvesse êste manancial de prosperidade pública.

"As comissões, pôsto que tenham terminado o seu trabalho, não podem ainda submetê-lo à discussão e aprovação do corpo legislativo, por não caber no curto espaço de tempo, que resta das sessões dêste ano, e apresentarem-se as cópias necessárias, o que farão logo que prontas estejam, reservando-se para emitir então o seu parecer acêrca do método que julgam preferível para a discussão do cóm digo, oferecendo o projeto de lei para sua aprovação.

"Entretanto pensam as comissões, que faltariam à justiça, se fazendo esta exposição não confessassem que os Srs. JOSÉ CLEMENTE PEREIRA e LOURENÇO WESTIN, membros da comissão nomeada pelo govêrno para a organização do código do comércio, os quais foram convidados para assistirem às conferências das comissões, prestaram-se de muito bom grado, muito concorreram com as suas luzes para o melhoramento desta obra, em que tinham não pequena parte".
Não se incorporou ao parecer o trabalho da comissão de Senadores e Deputados. Dêle resultou substitutivo, com as inúmeras emendas apresentadas, muitas por LOURENÇO WESTIN, apontando erros, omissões ou inutilidades do projeto, de que fôra colaborador exímio.

10. Estagnado o projeto na Câmara dos Deputados; recomposta, em 1836 e em 1837, a comissão especial para seu estudo constituída, o problema entrou a debater-se nos círculos comerciais. De tôda a parte afluíram emendas, sugestões, substitutivos, que se encominharam à Câmara dos Deputados. Chegou mesmo LOUREN COO WESTIN a formular novo projeto, refundindo o primitivo.

Aproveitando o abundante material que se foi aglutinando, a comissão de Senadores e Deputados, recomposta pelas contingências do tempo decorrido, prosseguiu no trabalho; e, não querendo "fiar só da sua inteligência o juízo que lhe competia emitir sôbre matérias tão transcendentes" julgou conveniente confiá-lo ao exame de três jurisconsultos - Drs. DIôGO SOARES DA SILVA DE BIVAR, ANTÔNIO JOSÉ COELHO LOUZADA e CAETANO ALBERTO SOARES, os quais contribuíram com observações judiciosas, redigindo-se, de acôrdo com elas, novo projeto.

$\mathrm{O}$ parecer, oferecido à Câmara dos Deputados em 28 de agôsto de 1843, assim concluiu :

"E como no entender das comissões reunidas o novo projeto, suposto não possa dizer-se obra perfeita, pode ser adotado sem grave inconveniente na prática, deixando-se à experiência do tempo as emendas de que possa carecer; atendendo-se à urgente necessidade que existe de estabelecer certas regras que regulem a decisão das questões comerciais, sujeitas até hoje ao livre arbítrio que a lei de 18 de agôsto de 1769 deixou aos julgadores de recorrerem às leis econômicas, mercantís e marítimas das nações cristãs, iluminadas e polidas; considerando também que petições de comerciantes de diversas praças do Império têm sido apresentadas a ambas as Câmaras, pedindo medidas legislativas que ponham têrmo aos males que o comércio padece por falta de um código comercial; e observando finalmente que uma discussão por artigos fôra absolutamente impraticável:

"É a comissão de parecer, de acôrdo com a comissão da Câmara dos Srs. Senadores, que o novo projeto redigido pelas suas comissões se discuta em globo, aprovando-se ou rejeitando-se como parecer à sabedoria desta augusta Câmara".

Não continha novidade a proposta, pois que assim se fizera quanto a outros projetos, entre os quais o do código criminal; e a mesa da Câmara no mesmo sentido se pronunciou, considerando:

" $1 .^{\circ}$, que o debate de cada um dos 947 artigos, de que êle 
consta, teria de retardar por muito tempo a promulgação de uma lei, cuja falta se torna dia-a-dia mais sensível;

" $2 .^{\circ}$, que o projeto em questão, depois de revisto por várias comissões, não só das câmaras legislativas, como externas, acha-se já impresso e distribuído a cada um dos Srs. Deputados, que examinando-o, poderá ainda lembrar alguma correção que seja necessária;

"3..$^{\circ}$, que em casos idênticos, e por diversas razões de utilidade pública, tem a Câmara resolvido dispensar algumas das disposições do regimento que regulam o andamento dos seus trabalhos" - e opinando por que o projeto tivesse uma só discussão, correspondente à terceira.

Largo debate suscitou o parecer da Mesa, manifestando-se uns em seu prol e contra outros, vindo a tornar-se vencedora proposta de que se sustasse a discussão, formulada pelo Deputado ANGELO MONIZ DA SILVA FERRAZ, da Bahia, e que veio a ser o Barão de Uruguaiana. Não se contentou êle com isso. Sugeriu mais que se remetesse o projeto à Praça do Comércio do Rio de Janeiro para que, no intervalo a decorrer até 1 de maio de 1844, a comissão fizesse subir a plenário suas observações e emendas, de molde "à Câmara mais ilustrada discutir a matéria".

Instalada nova legislatura em 1845 , reconstituída, por isso mesmo, a comissão especial do projeto do código comercial e dado por ela parecer para que se prosseguisse na discussão suspensa em 1843, reabriu-se ela, larga e brilhante vindo a encerrar-se em 17 de julho, quando se aprovou a redação da matéria vencida.

11. Enviado o projeto ao Senado, deu-lhe a câmara vitalícia singular relêvo pela quantidade e qualidade das emendas que, no decurso dos debates, se apresentaram, em número de 482, supressivas, aditivas ou substitutivas, abrangendo todo o contexto. Não deixou capítulo algum de exame meticuloso, o que denota o empenho, que os Senadores puseram no aprimoramento da obra, em que foram chamados a colaborar.

Entrando em plenário o projeto com o parecer elaborado pela comissão mista de Senadores e Deputados, que já havia sido apresentado à Câmara dos Deputados em sessão de 29 de agôsto de 1843, o Senado, em sessão de 9 de setembro de 1845, deliberou que a discussão viesse a fazer-se no ano seguinte.

Assim aconteceu.

Travou-se a primeira discussão nos primeiros dias de maio de 1846. Nos três meses subseqüentes deu-se a segunda discussão, por títulos, aprovando-se, com as respectivas emendas, os dezoito títulos da parte primeira - a do Comércio em geral. Também por títulos se discutiu a segunda parte - a Do Comércio marítimo, aprovando-se as emendas que lhe condiziam, até ao título decimo- terceiro. Suspensa a discussão, prosseguiu em 1848, ultimando-se a da segunda parte, e continuando a da terceira - a Das Quebras, seguida do título único - a $\mathrm{Da}$ Administração de Justiça nos $\mathrm{Ne}$ gócios e Causas Comerciais.

Nos embates políticos de 1848, três gabinetes se sucederam o de 8 de março, presidido por JOSÉ CARLOS PEREIRA DE ALMEIDA TORRES, Visconde de Macaé; o de 31 de maio, presidido por FRANCISCO DE PAULA SOUSA E MELO; e o de 29 de setembro, presidido por PEDRO DE ARAUJO LIMA, Visconde de Olinda.

Ocupava a pasta da Justiça do gabinete de 31 de maio o Deputado ANTÔNIO MANUEL DE CAMPOS MELO, de São Paulo; e quando o projeto ia entrar em terceira discussão, solicitou êle ao Senado que a adiasse por quinze dias, de modo a coparticipar dela. Desfechou-se, por partes, nas sessões de agôsto, vindo a aprovar-se na de 28 de setembro a redação final. No dia seguinte, com o novo gabinete assumiu o Deputado EUSÉBIO DE QUEIROZ COUTINHO MATOSO DA CÂMARA, da Província do Rio de Janeiro, o Ministério da Justiça.

E o projeto do código comercial, com as emendas do Senado, retornou à Câmara dos Deputados.

12. Dissolvida, a Câmara dos Deputados não funcionou em 1849.

Instalada a oitava legislatura de 1850 , nela se entrou a examinar as emendas oriundas do Senado. Foram tantas que o Deputado do Pará, BERNARDO DE SOUSA FRANCO, que viria a ser o Barão de Sousa Franco, asseverou, da tribuna, que elas constituíam "todo o código". Assinalou-se, nessa frase, a importância das emendas senatoriais, mercê das quais o projeto como que se havia transfigurado. Desejou aquêle deputado, por isso mesmo, que a discussão se fizesse por partes, correspondendo cada uma a uma das quatro partes do projeto: mas essa proposta não mereceu o apoio do plenário.

Aceitou êste, em sessão de 6 de março, as emendas do Senado; e, na de 22 , aprovou a redação final do projeto, que chegou ao têrmo da elaboração parlamentar.

13. Aos 2 de maio subiu o projeto à sanção, levado à presença imperial, de conformidade com os dispositivos constitucionais, por deputação de sete membros da câmara eletiva, portadora da mensagem de estilo:

"A Assembléia Geral dirige ao Imperador o decreto incluso, que julga vantajoso e útil ao Império, e pede a Sua Majestade Imperial se digne dar a sua sanção".

Consentiu o Imperador, dando-lhe sua sanção. Promulgou-se, pela lei n. ${ }^{\circ} 556$, de 25 de junho de 1850, o Código Comercial do 
Império do Brasil, referendado por EUSÉBIO DE QUEIROZ COUTINHO MATOSO CÂMARA, Ministro da Justiça. Publicado em 1 de julho, entrou em vigor a 1 de janeiro de 1851 .

14. Examinado no seu conjunto e pôsto em confronto com as demais leis brasileiras de seu tempo, o código comercial bem merece os entusiásticos adjetivos com que foi qualificado. Se a Câmara dos Deputados recebeu o projeto, em que se converteu, com certa perpléxidade, perfeitamente compreensível no tempo em que sôbre êle se manifestou; o Senado não se deixou dominar pelo mesmo sentimento, dedicando-lhe estudo percuciente e profundo.

Eis porque, no conceito de CÂNDIDO MENDES DE ALMEIDA, foi a lei "das mais debatidas e esmerilhadas do nosso corpo de legislação. Se tôdas passassem por igual prova seriam menos defeituosas. O nosso código, cumpre dizê--lo, pôsto em confronto com legislação similares, não tem de que enrubecer; e quaisquer que sejam os senões que o mareiem como obra humana, não são tais que fàcilmente se não possam remediar; por certo não afetarão os princípios essenciais da jurisprudência marítimo-comercial. Para nós tem êle ainda um grande mérito. Conquanto a jurisprudência comercial e marítima se possa chamar cosmopolita, e a tal ponto que o que se legislasse para um país poder-se-ia aplicar integralmente em qualquer outro, o código que elaboramos tem o característico de, aceitando e admitindo os princípios gerais e uniformes dessa legislação peculiar, consagrar com êles as práticas e usos de há muito em voga em nossas praças, e que uma boa razão sancionava e reclamava a continuação. Há pois uma legislação firmada com o cunho brasileiro, revelando entre outros dotes, no espírito e na redação, o labor e colorido pátrios" $\left({ }^{9}\right)$.

Qualidade de monta é, dessarte, a que lhe atribuiu o consagrado jurista, e nunca denegada, antes acentuada poderosamente. O código comercial revestiu-se de sentido nitidamente brasileiro. Destinou-se a servir o comércio do Brasil e nas suas práticas e nos seus usos encontrou as fórmulas e delas deduziu os princípios gerais a que se submeteu para formar o contexto homogêneo que lhe asseguraria vigência secular.

15. Por tôdas as circunstâncias e efeitos da tradição histórica, muito haveria o código brasileiro de abeberar no português de 1833 , redigido pelo grande jurisconsulto lusitano JOSÉ FERREIRA BORGES. Vivíamos sob a regência das velhas ordenações portuguêsas e o comércio do Brasil, até 1807 , sòmente se fazia por intermédio do de Portugal, mercê do monopólio de que se investiu a metrópole, dominando e dirigindo o da sua colônia da América.

(9) JOSÉ DA SILVA LISBOA, Principios de Direito Mercantỉ e Leis de Mari nha, 6.a ed. da Tipografia Acadêmica (
Mendes de Almeida, pág. DCXLVIII).
Não se fêz, todavia, a cópia vulgar. Bem o salientou o comercialista espanhol LORENZO BENITO, quando, referindo-se a a Brasil, escreveu que "esta República tiene desde 25 junio de 1850 un notable Código de Comercio, que aún que inspirado en el portugués, introdujo una porción de innovaciones, que le hacen muy apreciable por muchos conceptos" $\left({ }^{10}\right)$. No sentir de outro tratadista espanhol, FRANCISCO BLANCO CONSTANS, êle foi "muy notable por cierto para su época" (11)

Igualmente se manifestou DIDIMO DA VEIGA, quando observou que, "encarado em face dos códigos alemão, húngaro e italiano que constituem a expressão da atualidade da ciência do direito comercial, êle deve ser considerado atrasado; como representando um produto da ciência e prática comercial da época de sua promulgação, não pode deixar de ser reputado um excelente espécime de codificação $\left({ }^{12}\right)$.

Não é possível, de feito, dizer do valimento de lei, de código especialmente, senão no tempo e no espaço. Não se legisla no vácuo, mas para determinar povos que vivem, labutam, sofrem e morrem em certos lugares do globo, em que a neve durante meses cobre os montes e as várzeas e as noites são mais longas do que os dias; em que o sol, glorioso e fecundo, os anima de vegetação permanente em primavera que dura o ano inteiro. A cada qual sua lei; pois que os costumes de uns assaz diferem dos de outros.

Com a sua sabedoria imensa o velho MONTESQUIEU observou que "les lois doivent être tellement propres au peuple pour lequel elles sont faites que c'est un trés grands hasard si celles d'une nation peuvent convenir à une autre". Êsse foi o princípio que não perderam de mente os que se encarregaram de escrever o código comercial do Brasil. Tiveram diante dos olhos, e nobremente o confessaram, os códigos até então promulgados, que não eram muitos. Entre êles, o de Portugal. Tendo o Brasil vivido, até então, e continuado a reger-se pelas velhas leis portuguêsas, que de muito tinham cessado sua vigência na terra lusitana, demasia não seria, por certo, a influência que o código português pudesse exercer sôbre o brasileiro. Mas isso não aconteceu senão no que o texto português possuía de universal, mercê do cosmopolitismo do comércio e do seu incontrastável particularismo. Nesse ponto, todos os códigos se parecem.

No mais, o código brasileiro sofreu as contingências locais e muitíssimo bem as traduziu e compendiou. E que, como bem obser-

(10) LOURENZO BENITO, Manual de Derecho Miercantil, $3 .^{a}$ ed. Victoriano Suárez (Madrid, 1924, vol. I, pág. 201, n. 159 ). til, 3.a ed. Reus (Madrid, 1910, vol. I, pág. 260). \& (12) DIDIMO AGAPITO DA VEIGA, Óddigo Comercial Comentado, ed. Laemmert 
vou PORTALIS, "on ne fait pas un code; il se fait avec le temps". Jamais conceito de tanta procedência se aplicou com mais justeza do que no caso do código comercial brasileiro. Tanto que terminado pela comissão incumbida pelo govêrno de escrevê-lo, encaminhou-se à Câmara dos Deputados, que o aceitou qual se concebera. Transmitido ao Senado, depois de decorridos quase quinze anos, tais e tantas emendas lá se aprovaram, que o código ganhou outro aspecto. Precisamente, êle se fêz com o tempo.

Por isso mesmo, mercê de tremendo paradoxo, o tempo ainda não o consumiu. Está o velho código a atingir o seu centenário, que hoje se começa a comemorar nesta Faculdade de Direito de São Paulo. Nessa ancianidade está o seu melhor e maior elogio. Padeceu, como era natural, as agruras do tempo. Desdobrou-se em inúmeras leis que não o descarnaram, antes contribuíram por que sua vigência se prolongasse, atestando a rijeza do seu cerne, afundando-se as suas raízes no subsolo da consciência jurídica da nação, de que extraiu a linfa que o animou, conservando ainda verde a galharada que os anos não lograram secar.

\section{O CÓDIGO COMERCIAL NO SÉCULO \\ Hernani Estrella}

Professor Catedrático de Direito Comercial na Faculdade de Direito da Universidade do Rio Grande do Sul.

I

\section{CÓDIGOS CENTENÁRIOS}

1 - Reveste-se de especial significação a passagem do Centenário do Código Comercial. Acontecimento sem precedente entre nós e só verificado na França, em relação aos dois códigos napoleônicos, está, por isso mesmo, a exigir registro condigno. Se entre os franceses, e em tôda a Europa continental, o transcurso de cem anos de vida daquelas codificações provocou estudos brilhantes e de variado conteúdo, também aqui, embora em proporções òbviamente menores, outro tanto, certamente, se verificará. É verdade que a ressonância suscitada pela efeméride francesa não decorreu da simples vetustez dos dois códigos, fato êste, aliás, sobremodo significativo, como expressão de estabilidade da lei, em face das contínuas mutações do comércio jurídico. A relevância que o acontecimento assumiu adveio, principalmente, das idéias sob cuja inspiração foram elaborados aqueles estatutos e da projeção que essas mesmas idéias tiveram nas codificações levadas a efeito, posteriormente, por vários países.

2 - Condensando, depurando e inovando, sob muitos respeitos, l'ancien droit, atualizando o direito romano e o direito canônico, o código francês conciliou, em certa medida, a tradição jurídica com as conquistas da Revolução. Nem se prendeu inteiramente àquela, nem se deixou seduzir pelo facínio desta. Não foi obra de uma escola e muito menos expressão de um sistema de doutrinas.

Nesse ecletismo, viu MARCEL PLANIOL ${ }^{(1)}$, ao lhe saudar o centenário, a razão de seu vigor e de sua longa durabilidade, explicados nestas palavras: "O que fêz a fôrça do código Napoleão foi que seus autores não se aproveitaram da ocasião que se lhes

1) Livre du Centenaire. 